\title{
Gene Expression of Formyl Peptide Receptor 1 in Eosinophils of Iraqi Patients with Extrinsic Allergic Asthma
}

\author{
Raed F. Alaouadi(FICMS), Abdul-Kareem Salman Saqban (Ph. D) \\ Al-Qasim Green University, College of Veterinary Medicine ,Iraq.
}

\begin{abstract}
The formyl peptide receptor 1 (FPRI) is a member of the seven transmembrane G-protein coupled receptors family, mainly expressed by polymorphonuclear and mononuclear phagocytes and play a role in chemotaxis, killing of microorganisms through phagocytosis, and plays a important role players in innate immunity and host defense. The expression of (FPRI) in eosinophils has been investigated intensively with many diseases. In this study we explain regulation of (FPRI) expression in eosinophils during allergic disease such as (extrinsic Asthma). The study were conducted by using Reverse Transcription Real-Time PCR technique, and the fold changes of (FPR1) were estimated in the house dust mite (HDM) hypersensitive asthmatic patients group and birch pollen hypersensitive asthmatic patients group as well as healthy control group. The results show that there are high significant increase fold changes of (FPRI) expression (up regulation) in eosinophils of HDM hypersensitive asthmatic patients group. In contrast, birch pollen hypersensitive asthmatic patients group have no significant increase in FPRl expression when compared with healthy control group. In conclusion, we concluded that formyl peptide receptor 1 (FPRI) that expressed by eosinophils have potential role in immune regulation and allergic diseases mainly extrinsic asthma when patients exposed to exogenous aggressive factor such as house dust mite.
\end{abstract}

\section{Introduction}

The formyl peptide receptor 1 (FPR1) belongs to a family of G protein-coupled recognition receptors, which are mainly expressed by mammalian phagocytic leukocytes and are key players in innate immunity and host defense $(1,2,3)$. In neutrophils, signaling through the FPR1 receptor plays a role in chemotaxis, killing of microorganisms through phagocytosis, and generation of reactive oxygen species (2). Whereas, in eosinophils, the studies refer that the FPR 1 receptor plays a role in chemotaxis to inhalant allergens such as house dust mite (HDM), birch and grass pollens, cat dander and cockroach extracts and lead to triggering of chemotactic behavior $(4,5,6)$. In addition, FPR1 is thought to play a role in sensing of endogenous signals of dysfunctional cells, which should attract leukocytes to the site of inflammation and tissue damage (2). Allergic reactions such as extrinsic allergic asthma and allergic rhinitis are inflammatory response that develops in response to environmental allergens (7). Eosinophils are granulocytes that appear to have a particular affinity for inhalant allergens, the hallmark of allergic diseases. Eosinophils are vital in the late stage of development of extrinsic allergic asthma (8). Airborne environmental allergens can directly activate eosinophils from healthy non allergen individual house dust mite allergen events the activation via formyl peptide receptor FPR (9). Asthma is a chronic respiratory disease characterized by recurring attacks of impaired breathing of varying intensities. Over $20 \%$ of the word population suffers from IgE mediated allergic disease such as asthma and allergic rhinitis (10).

FPR1 is highly expressed in myeloid cells like neutrophils, monocytes and macrophages, while the expression of FPR1 in neutrophils and macrophages has been investigated intensively (11), knowledge on regulation of FPR1 expression in eosinophils is lacking. This study aimed to investigate the regulation of FPR1 expression in eosinophils whether house dust mite or birch pollen have a role in activation of $\mathrm{N}$ - formyl peptide receptors.

\section{Blood samples collection}

\section{Materials and Methods}

Thirty six blood samples were collected from investigated extrinsic asthmatic patients (21 patients with HDM hypersensitivity and 15 patients with birch pollen hypersensitivity confirmed by skin prick test to the corresponding allergen extract) in addition to 17 healthy persons who conducted Asthma and Allergy Center in Babylon Province by using EDTA-collected tubes. Then the samples transported to laboratory and stored in deep freezer.

\section{Total RNA Extraction}

Total RNA were extracted from blood samples by using (Accuzol@ reagent kit. Bioneer. Korea) and done according to company instructions as follow; $300 \mu \mathrm{l}$ of blood sample was placed in $1.5 \mathrm{ml}$ eppendorf tube 
and $1 \mathrm{ml}$ of Accuzol reagent was added and the tubes shaken vigorously for 1 minute. Then, $200 \mu 1$ chloroform added to each tube and shaken vigorously for 15 seconds. Then the mixture was incubated on ice for 5 minutes, and then centrifuged at $12000 \mathrm{rpm}, 4 \mathrm{C}^{\circ}$, for 15 minutes. The supernatant transferred into a new eppendorf tube, and $500 \mu \mathrm{l}$ isopropanol was added. Then, mixture mixed by inverting the tube $4-5$ times and incubated at $4 \mathrm{C}^{\circ}$ for 10 minutes. Then, centrifuged at $12000 \mathrm{rpm}, 4 \mathrm{C}^{\circ}$ for 10 minutes. The supernatant was discarded, and $1 \mathrm{ml}$ $80 \%$ Ethanol was added and mixed by vortex again. Then, centrifuge at $12000 \mathrm{rpm}, 4 \mathrm{C}^{\circ}$ for 5 minutes. The supernatant was discarded and the RNA pellet was left to air to dry. Finally $50 \mu 1$ DEPC water was added to each sample to dissolve the RNA pellet, and then the extracted RNA sample was kept at -20.The extracted total RNA was assessed and measurement by Nanodrop spectrophotometer (THERMO. USA).

\section{DNase I Treatment}

The extracted RNA were treated with DNase I enzyme to remove the trace amounts of genomic DNA from the eluted total RNA by using (samples DNase I enzyme kit) and done according to method described by Promega company, USA instructions as follow:

\begin{tabular}{|c|c|}
\hline Mix & Volume \\
\hline Total RNA 100ng/ ul & $10 \mathrm{ul}$ \\
\hline DNase I enzyme & $1 \mathrm{ul}$ \\
\hline 10X buffer & $4 \mathrm{ul}$ \\
\hline DEPC water & $5 \mathrm{ul}$ \\
\hline Total & $20 \mathrm{ul}$ \\
\hline
\end{tabular}

After that, The mixture was incubated at $37 \mathrm{C}^{\circ}$ for 30 minutes. Then, $1 \mu \mathrm{L} 25 \mathrm{mM}$ EDTA was added and incubated at $65 \mathrm{C}^{\circ}$ for 10 minutes for inactivation of DNase enzyme action.

\section{cDNA synthesis}

DNase-I treatment total RNA samples were used in cDNA synthesis step by using AccuPower ${ }^{\circledR}$ RocktScript RT PreMix kit that provided from Bioneer company, Korea and done according to company instructions as following table:

\begin{tabular}{|c|c|}
\hline RT master mix & Volume \\
\hline Total RNA 100ng/ul & $10 \mathrm{ul}$ \\
\hline Random Hexamer primer & $1 \mathrm{ul}$ \\
\hline DEPC water & $9 \mathrm{ul}$ \\
\hline Total & $20 \mathrm{ul}$ \\
\hline
\end{tabular}

This RT PreMix was placed in AccuPower RocktScript RT PreMix tubes that contains lyophilized Reverse transcription enzyme at form. Then dissolved completely by vortex and briefly spinning down.

The RNA converted into cDNA in thermocycler under the following thermocycler conditions:

\begin{tabular}{|c|c|c|}
\hline Step & Temperature & Time \\
\hline cDNA synthesis (RT step) & $50^{\circ} \mathrm{C}$ & 1 hour \\
\hline Heat inactivation & $95^{\circ} \mathrm{C}$ & 5 minutes \\
\hline
\end{tabular}

\section{Quantitative Real-Time PCR (qPCR)}

qPCR was performed for quantification of FPR1 mRNA transcript levels whereas, relative gene expression analysis was carried out by using $\left(2^{-\Delta \Delta C T}\right.$ Livak method) (Livak and Schmittgen, 2001) (12).The qPCR reaction was done on a Real-Time PCR system (BioRad. USA) by using SYBER Green dye qPCR master mix that used in detection and amplification of FPR1 target gene and GAPDH housekeeping gene for normalization of gene expression. Primers were designed using the primer3 plus (Primers sequences are listed in Table 4).

\begin{tabular}{|c|c|c|c|c|}
\hline Primer & \multicolumn{2}{|c|}{ Sequence } & $\begin{array}{c}\text { Amplicon } \\
\text { size }\end{array}$ & Gene Bank \\
\hline FPR1 & F & CTGAGTCACTCTCCCCAGGA & 189bp & NM_001193306.1 \\
\hline
\end{tabular}


Gene Expression of Formyl Peptide Receptor 1 in Eosinophils of Iraqi Patients with Extrinsic...

\begin{tabular}{|c|c|c|c|c|}
\hline & $\mathbf{R}$ & CCAGGAAGAGATAGCCAGCA & & \\
\hline \multirow{2}{*}{ GAPDH } & $\mathbf{F}$ & CCCATGTTCGTCATGGGTGT & \multirow{2}{*}{ 145bp } & \multirow{2}{*}{ NM_002046.3 } \\
\hline & $\mathbf{R}$ & TGGTCATGAGTCCTTCCACGATA & & \\
\hline
\end{tabular}

qPCR master mix was prepared for FPR1 target gene and GAPDH housekeeping gene according to (AccuPower ${ }^{\mathrm{TM}} 2 \mathrm{XGreen}$ Star qPCR master mix kit. Bioneer .Korea)instructions as following table5:

\begin{tabular}{|c|c|}
\hline qPCR master mix & volume \\
\hline cDNA template (10ng) & $5 \mu \mathrm{L}$ \\
\hline Forward primer (10pmol) & $1 \mu \mathrm{L}$ \\
\hline Reverse primer(10pmol) & $1 \mu \mathrm{L}$ \\
\hline 2X green star master mix & $25 \mu \mathrm{L}$ \\
\hline DEPC water & $18 \mu \mathrm{L}$ \\
\hline Total & $50 \mu \mathrm{L}$ \\
\hline
\end{tabular}

After that, qPCR master mix reaction component that mentioned above placed in qPCR white tube strips and mixed by (Exispin vortex centrifuge, Bioneer. Korea) for 3 minutes, than the strips placed in Miniopticon Real-Time PCR system( BioRad. USA) as following thermocycler conditions table 6:

\begin{tabular}{|c|c|c|c|}
\hline qPCR step & Temperature & Time & Repeat cycle \\
\hline Initial Denaturation & $50{ }^{\circ} \mathrm{C}$ & 1 hour & 1 \\
\hline Denaturation & $95^{\circ} \mathrm{C}$ & $20 \mathrm{sec}$ & \multirow{2}{*}{45} \\
\hline $\begin{array}{c}\text { Annealing\ Extension } \\
\text { Detection(scan) }\end{array}$ & $60{ }^{\circ} \mathrm{C}$ & $30 \mathrm{sec}$ & 1 \\
\hline Melting & $60-95^{\circ} \mathrm{C}$ & $0.5 \mathrm{sec}$ & \\
\hline
\end{tabular}

\section{Results}

Allergic asthma is activated by Eosinophils cells via activation of formyl peptide receptor FPR1 in their surface. The regulation of the FPR1 gene in Eosinophils in house dust mite and birch pollen patient's samples, through the relative mRNA expression (that normalized for GAPDH mRNA expression ) was investigated by RT-qPCR technique (Figure: 1,2).

Figure (1): Real-Time PCR amplification plot (A), Real-Time PCR SYBER green melt peak of formyl peptide

receptor (FPR1) gene in house dust mite group (red), birch pollen group (blue), and healthy control

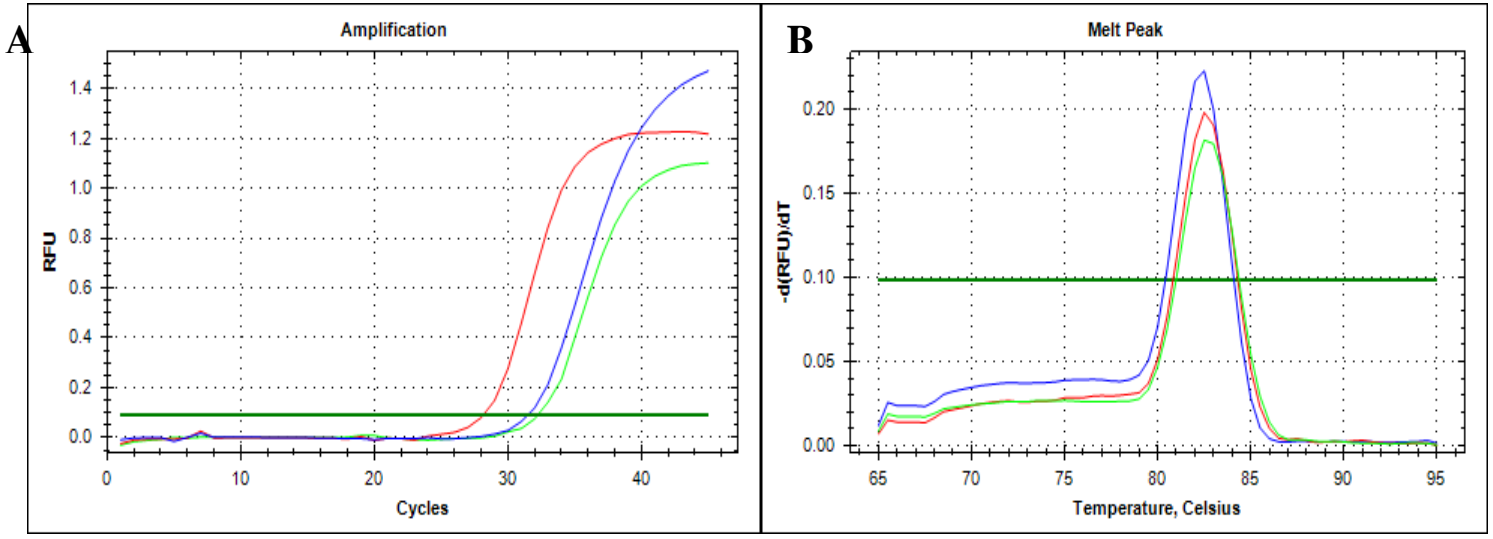

group (green) 

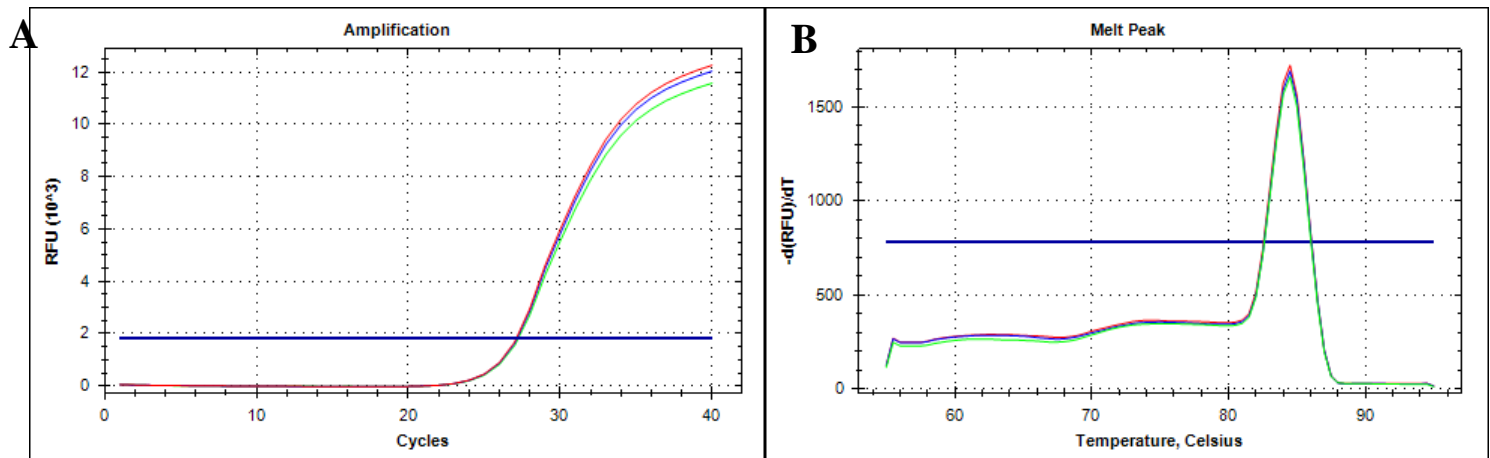

Figure (1): Real-Time PCR amplification plot (A), Real-Time PCR SYBER green melt peak of reference gene (GAPDH) in house dust mite group (red), birch pollen group (blue), and healthy control group

(green)

Our results revealed that The Eosinophils express high levels of FPR1 on the cell surface in allergic asthmatic patients, especially in house dust mite hypersensitive patient groups in contrast to birch pollen hypersensitive patient groups. Where, the results of mRNA FPR1 gene relative expression which appeared very high increased (up regulation) in house dust mite hypersensitive asthmatic patient groups at mRNA transcript level (14.41 \pm fold change). Whereas, birch pollen hypersensitive asthmatic patient groups which appeared little increase of mRNA FPR1 gene relative expression (2.13 \pm fold change) relative to healthy control patients groups. Table (1) and Figure (3)

Table (1): The relative gene expression analysis of formyl peptide receptor (FPR1) gene by $2^{-\Delta \Delta C \mathrm{~T}} \mathrm{Livak}$ method.

\begin{tabular}{|c|c|c|c|c|c|c|}
\hline Group & $\begin{array}{c}\text { Mean } \\
\text { CT } \\
\text { FPR1 }\end{array}$ & $\begin{array}{c}\text { Mean CT } \\
\text { GAPDH }\end{array}$ & $\begin{array}{c}\Delta \text { CT } \\
\text { (Test) }\end{array}$ & $\begin{array}{c}\Delta \text { CT } \\
\text { (control) }\end{array}$ & $\Delta \Delta$ CT & $\begin{array}{c}\text { Fold change } \\
\left(2^{\wedge}-\Delta \Delta \text { CT) }\right. \\
\text { Mean } \pm \text { St. error }\end{array}$ \\
\hline T1 & 28.825 & 26.43 & 2.395 & 6.22 & $\mathbf{- 3 . 8 2 5}$ & $\mathbf{1 4 . 4 1} \pm 3.9452$ \\
\hline T2 & 31.715 & 26.4975 & 5.2175 & 6.22 & -1.0025 & $\mathbf{2 . 1 3} \pm 0.4147$ \\
\hline
\end{tabular}

T1: house dust mite hypersensitive patients group,T2: birch pollen hypersensitive patients group ,C: healthy control group

$\left(2^{-\Delta \Delta C T}\right.$ Livak method) include: First, the CT of the target gene FPR1 was normalized to that of the reference (ref) GAPDH gene, for both the test patients group and control group as following two formula:

$\Delta C T($ test $)=C T($ target, test $)-C T($ ref, test $)$

$\Delta C T($ control $)=C T($ target, control $)-C T($ ref, control $)$

Second, the $\Delta \mathrm{CT}$ of the test patients group were normalized to the $\Delta \mathrm{CT}$ of the control group

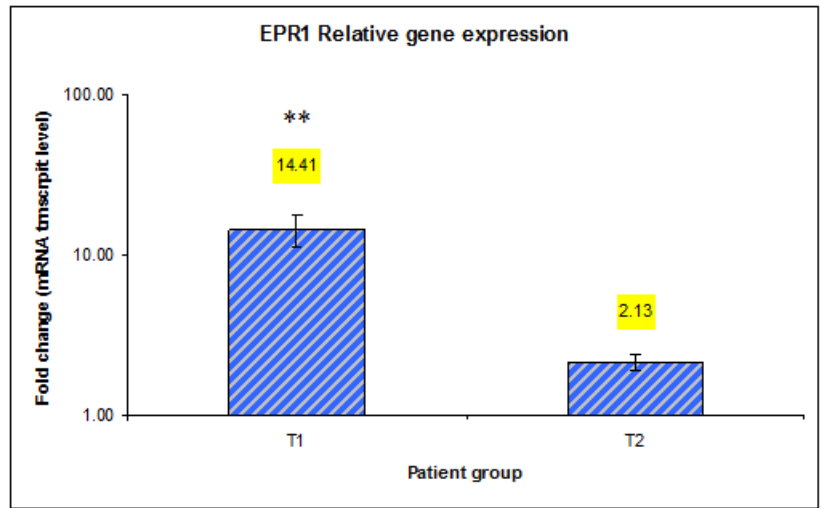

Figure (3): Regulation of FPR1 mRNA expression in human eosinophils.(T1) Relative mRNA expression of FPR1 in house dust mite hypersensitive patients group and (T2) Relative mRNA expression of FPR1 in birch pollen hypersensitive patients group. The values are normalized for GAPDH mRNA expression and are presented relative to non-stimulated control macrophages (black). Bars display the mean and the standard Error (ST.E) of three independent experiments, significant at $* * \mathbf{p}<0.05$. 


\section{Discussion}

We studied the regulation of FPR1 receptor expression in eosinophils cell surface of extrinsic allergic asthmatic patients. The study was carried out by quantitative Reverse Transcription real time PCR technique. This technique it also used by (13) who study the regulation of the formyl peptide receptor 1 (FPR1) gene in primary human macrophages. Our study shows that Eosinophils express high levels of FPR1 on the cell surface in allergic asthmatic patients in response to chemoattractants. The activation of formyl peptide receptor 1 has been observed in leukocytes from patients suffering from Crohn's disease or emphysema indicating thatFPR1 expression on leukocytes may serve as a marker for systemic inflammation(14,15). Our results show up regulation in mRNA FPR1 gene relative expression in house dust mite hypersensitive asthmatic patient. These result was agreed with (4) who show that Eosinophils stimulated with an extract from house dust mite (HDM) released the granule protein major basic protein (MBP) and up-regulated the surface receptor expression. in contrast to birch pollen hypersensitive asthmatic patient groups, our result also show that there are increased in mRNA FPR1 gene relative expression relative to healthy control patients mRNA FPR1 gene expression. This agreed with (5) who that show the eosinophils accumulation at sites of allergic inflammation is largely regulated by chemokines that induced by pollen-associated lipid mediators. In conclusion, we concluded that formyl peptide receptor 1 (FPR1) that expressed by eosinophils have potential role in allergic diseases mainly asthmatic patients exposure to exogenous aggressions such as house dust mite.

\section{Reference}

[1] Carp H (1982). Mitochondrial N-formyl methionyl proteins as chemoattractants for neutrophils. J Exp Med 155: 264-275.

[2] Ye RD, Boulay F, Wang JM, Dahlgren C, Gerard C, et al. (2009). International Union of Basic and Clinical Pharmacology. LXXIII. Nomenclature for the formyl peptide receptor (FPR) family. Pharmacol Rev 61: 119-161.

[3] Rabiet MJ, Huet E and Boulay F (2007) The N-formyl peptide receptors and the anaphylatoxin C5a receptors: an overview. Biochimie 89: 1089-1106.

[4] Svensson, L., Rudin, A. and Wenners, C., Allergen extracts direct lymobilize and activate human eosinophils. Eur. J. Immunol. 2004. 34:1744-1751.

[5] Plotz, S. G., Traidl-Hoffmann, C., Feussner, I., Kasche, A., Feser, A., Ring,J., Jakob, T. and Behrendt, H., Chemotaxis and activation of human peripheral blood eosinophils induced by pollen-associated lipid mediators. J. Allergy Clin. Immunol. 2004. 113: $1152-1160$.

[6] Sohn, M. H., Lee, Y. A., Jeong, K. Y., Sim, S., Kim, K. E., Yong, T. S. and Shin, M. H. German cockroach extract induces activation of human eosinophils to release cytotoxic inflammatory mediators. Int. Arch. Allergy Immunol. 2004. 134: 141-149.

[7] Passalacqua G and Durham SR (2007). "Allergic rhinitis and its impact on asthma update: allergen immunotherapy". The Journal of Allergy and Clinical Immunology 119 (4): 881-91. doi:10.1016/j.jaci.2007.01.045.

[8] Walsh ER, Stokes K and August A. (2010). The role of eosinophils in allergic airway inflammation. Discov Med. 9(47):357-62.

[9] Redvall, Elin (2010). Human eosinophils and their activation by allergens via danger signal receptors. University of Gothenburg. Sahlgrenska Academy Institute of Biomedicine. Department of Infectious Medicine. Doctoral thesis.

[10] WHO. (2002). Prevention of Allergy and Allergic Asthma. Geneva, 8-9 January 2002.

[11] Devosse T, Guillabert A, D'Haene N, Berton A, De Nadai P, et al. (2009). Formyl peptide receptor-like 2 is expressed and functional in plasmacytoid dendritic cells, tissue-specific macrophage subpopulations, and eosinophils. J Immunol 182: 4974-4984.

[12] Livak, K. J. and Schmittgen, T.D. (2001). Analysis of relative gene expression data using real time quantitative PCR and the $2 \Delta \Delta \mathrm{C}(\mathrm{T})$ Method. Methods. 25(4): 402-408.

[13] Gemperle C, Schmid M, Herova M, Marti-Jaun J, Wuest SJ, Loretz C and Hersberger M. (2012). Regulation of the formyl peptide receptor 1 (FPR1) gene in primary human macrophages. PLOS ONE. 7(11):e50195.

[14] Stockley RA, Grant RA, Llewellyn-Jones CG, Hill SL and Burnett D (1994). Neutrophil formyl-peptide receptors. Relationship to peptide-induced responses and emphysema. Am J Respir Crit Care Med 149: 464-468.

[15] Anton PA, Targan SR and Shanahan F (1989). Increased neutrophil receptors for and response to the proinflammatory bacterial peptide formyl-methionyl-leucyl phenylalanine in Crohn's disease. Gastroenterology 97: 20-28. 